\title{
A Study On Investor's Attitude and Perception in Hassan District Towards Mutual Funds as an Investment Option
}

\author{
Roshan. $\mathrm{K}^{1}$ and GAP Sudhakar ${ }^{2}$ \\ ${ }^{1}$ Research scholar, ISBR Research Centre, Mysore University, India \\ ${ }^{2}$ Research guide, ISBR Research Centre, Mysore University, India
}

\begin{abstract}
Among various financial instruments which are based on capital markets mutual funds have evolved as a predominant investment instruments from two decades in India .But being a poor financially literate country the general population of India's majorly the tier two cities towns and village level are still not able to perceive the basic ideology of mutual fund instrument where the concept was designed to mitigate market risk by a collective approach utilizing a professional service for fund management to achieve pre determined objective of capital appreciation. Now mutual fund domain has witnessed innovation in terms of funds as well as service areas in our country. So a research is designed to investigate the perception and the attitude of investors in Hassan city, this approach can reveal the ideas of people towards fund selection ,way of investment and also their risk appetite. This research tries to bring out facts which can be useful to fund houses to understand investors psychology in emerging areas.
\end{abstract}

\section{KEY WORDS: MUTUAL FUNDS, PERCEPTION, ATTITUDE, HASSAN.}

\section{INTRODUCTION}

India has witnessed a total collection of fixed deposits into various banks amounting to rupees 6 lakh crores as on august 2020 which means the people of India are still traditional investors who rely on traditional investment. Mutual fund as a concept was introduced in 1963 by the government through unit trust of India, later many other government bodies introduced their own funds namely state bank group, Punjab national bank group etc. The real phenomenal changes occurred with security exchange board and The Association of Mutual Funds in India which came into existence in 90 "s decade. With these watch dogs in place people slowly started believing

\section{ARTICLE INFORMATION}

Received 29th Oct 2020 Accepted after revision 14th Dec 2020 Print ISSN: 0974-6455 Online ISSN: 2321-4007 CODEN: BBRCBA

Thomson Reuters ISI Web of Science Clarivate Analytics USA and Crossref Indexed Journal

\section{Clarivate
Analytics}

NAAS Journal Score 2020 (4.31)

A Society of Science and Nature Publication,

Bhopal India 2020. All rights reserved.

Online Contents Available at: http//www.bbrc.in/

Doi: http://dx.doi.org/10.21786/bbrc/13.15/16 and took courage to investment into emerging products like shares, scripts and mutual funds, bonds mainly.

After early 2000 decade Indian MF sector has seen an operational increase of fund house coming into India to operate seeing the potential market lying which was untapped. Today India has 44 fund houses with 2500 mutual fund scheme operating in various segments of capital market to exchange trade funds. Recently many product innovations is witnessed like thematic funds, health care funds and speciality funds which are aligned according to risk interest of the potential investors. What is a mutual fund is a question rarely understood by the commons in India, to define its a collective investment tool designed to give opportunities to retail or individual investor to put his small savings to large investments into a fund which is managed by a professional fund manager with domain knowledge and expertise, all these are well defined and regulated by the specified government bodies with laws and regulations. The retail investors can invest with limited knowledge into funds with objective of dividend returns or capital appreciation in long term horizon to meet his life financial goals. 
The mutual fund is well integrated product managed by a fund house and the investment is given as units to the retail or institutional investors which are based on capital markets and also updated daily in terms of information sharing. The investments collected by fund houses are called assets under management which are deployed into various markets to generate returns. India as on September 2020 has 27,74,146 crores. The AUM of the Indian MF Industry has grown from 6.57 trillion as on September 30, 2010 to 26.86 trillion as on September 30,2020 about 4 fold increases in a span of 10 years. India mutual fund investment according to the cities are categorized as two parts namely T15 which includes top 15 cities of India which nearly contribute around $65 \%$ of mutual business and the other is B15 means beyond 15 cities majorly the small cities ,towns, tier two cities come under this umbrella. Here it's witnessed the remaining contribution of 35\% towards mutual fund folios. From this it's evident that there is wide dispersion of investment awareness and perception towards mutual fund concept in India.

\section{Objectives of Research}

- To study the investors' attitude towards Mutual Fund concept

- To study how investor perceive mutual fund as a investment option

- To analyze the investors economic and social profile and orientation towards Mutual Funds.

- To study any bias or misconception towards mutual fund concept.

Design of Research: This research is done on descriptive approach supporting the data collected where analytical approach is used to analyze factors effecting decision making, which is controlled by their perception and attitude towards mutual fund concept. For the study purpose Hassan city has been considered which comes under b15 category.

Data Collection Methodology: The data which is required for the study is obtained by a structured questionnaire which consists of total 21 questions based on demographic factors and investment oriented elements. Secondary data were assimilated through AMFI websites and economic forums and news papers articles dedicated towards mutual fund industry.

\section{Sampling Plan}

Target Population: Hassan

Sampling Unit: Individual investors of Hassan city and District

Method of sampling: convenient sampling and Random Sampling

Sample size: 100

\section{Inference Of Research Question -}

When the sample population were asked about the various investment avenues which are easily available for investment. Mainly seven instruments were selected for the study based on market research. The population showed a strong inclination towards traditional products like fixed deposits, saving accounts where funds are kept for liquidity purpose. This question has proved banking products have more appeal and very popular among tier two cities. Real estate is also seen as invested but due to huge investment required initially its not a options for many, gold is seen as a investment by very less as it's just a ornamentally value and cultural boundary mask it as resell option when the prices fluctuate. Market based investment is the least where directly investment into shares as an investment is seen very less. Insurance which is also a savings tool is not so popular reveals the study as many does not like to invest into insurance due to varied reason like long term, less returns and many have not understood the concept of economic value of human life in terms of uncertainties. Lastly the mutual fund has evolved and slowly it has Opicked up the pace as many are showing inclination towards this concept as investment option to many.

what is the preferred investment segments do you prefer the most while investing your savings?

Preferred segment of Investment

\begin{tabular}{|l|c|}
\hline Real Estate & $15 \%$ \\
\hline Savings Account & $23 \%$ \\
\hline Fixed Deposit & $25 \%$ \\
\hline Gold & $5 \%$ \\
\hline Shares & $6 \%$ \\
\hline Insurance & $9 \%$ \\
\hline Mutual Finds & $17 \%$ \\
\hline
\end{tabular}

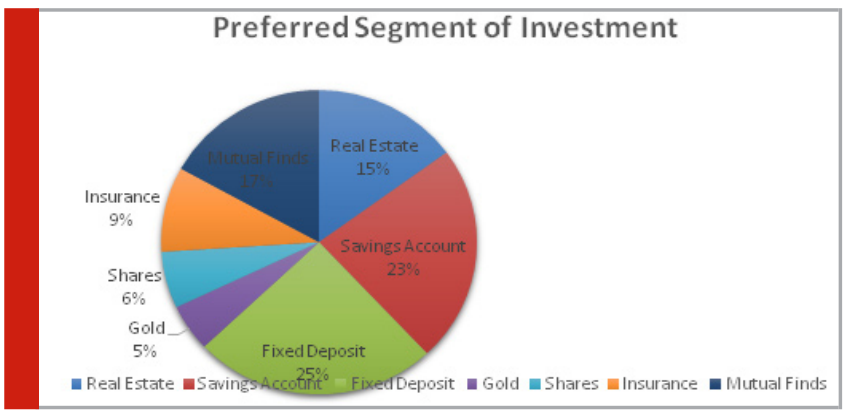

Which criterion affects your choice of investment the most?

Criteria that affects the investment options

\begin{tabular}{|l|c|}
\hline Risk & 10 \\
\hline Return & 35 \\
\hline Safety of principal & 40 \\
\hline Liquidity of Investment & 15 \\
\hline
\end{tabular}




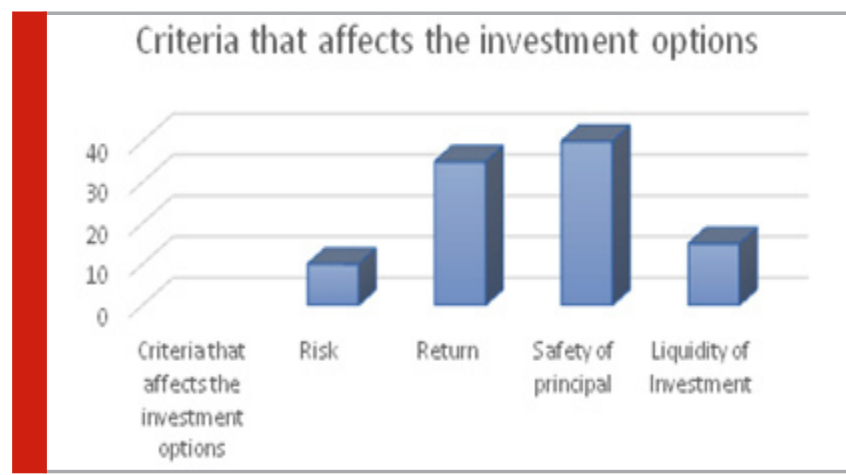

When the question of parking their funds which are earned hard way the sample population were asked which criteria they look and give the most important factor in considering an investment tool, the twin factor of safety of the amount invested as well as the return were considered as the most priority. Whereas liquidity and the risk also are considered while investments as future anticipation of uncertainties for health expenditure, planned life goals etc were opined out.

Have $u$ invested into mutual fund at least once in life time?

Investment in Mutual Funds atleast once in lifetime

\begin{tabular}{|l|l|}
\hline Yes & 38 \\
\hline No & 72 \\
\hline
\end{tabular}

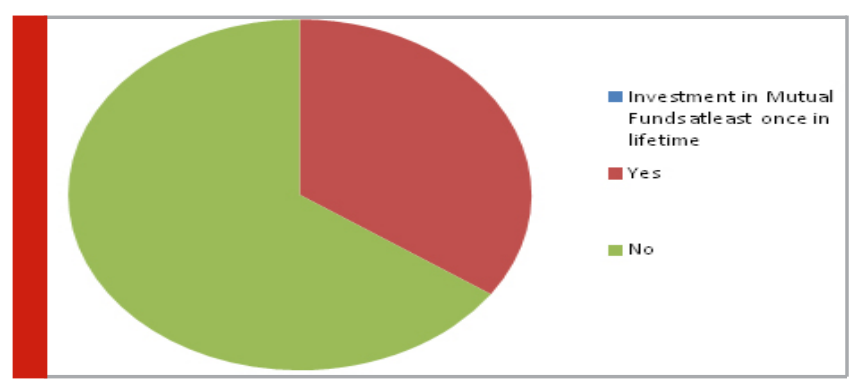

when the people were asked whether they have invested into mutual fund at least once in their life span as the idea behind the question the rationality was the mutual fund was in existence from almost three decades in India so people would had encountered this concept in one way or the other, the finding revealed that nearly 72 of the population have never invested into mutual fund concept ever.

Are you aware or heard of concept of mutual fund?

Awareness about Mutual Fund concept

\begin{tabular}{|l|l|}
\hline Yes & 60 \\
\hline No & 40 \\
\hline
\end{tabular}

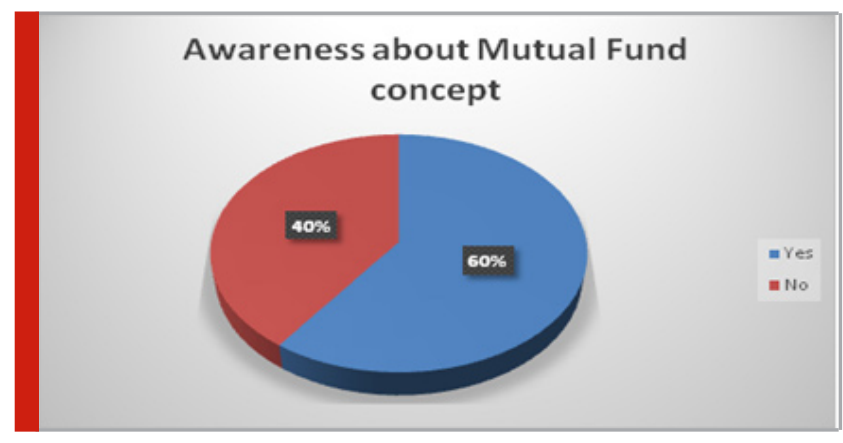

when the target were asked in any way they have heard about the concept of mutual fund or are they aware about the mutual funds in India, the research revealed that nearly $60 \%$ of people had come across the word mutual funds and they were aware of the concept. Whereas the remaining population had not heard about the mutual funds at all.

How did you come to know about mutual funds concept?

\section{Source of information about Mutual fund}

\begin{tabular}{|l|c|}
\hline Financial advisors & 20 \\
\hline Friends & 10 \\
\hline News paper & 15 \\
\hline TV Ad & 7 \\
\hline $\begin{array}{l}\text { Mail Advertisement and } \\
\text { social media }\end{array}$ & 9 \\
\hline colleagues & 6 \\
\hline Bank & 21 \\
\hline Independent online research & 12 \\
\hline
\end{tabular}

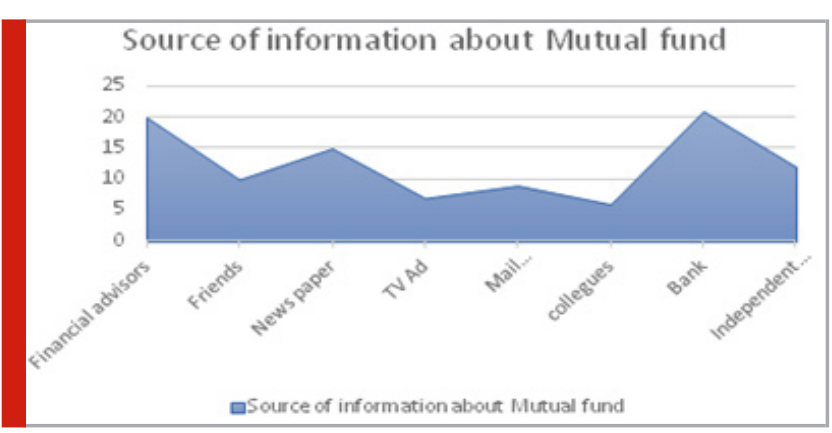

When $60 \%$ of the population accepted that they are aware of mutual fund, the research tried to find out from which sources they are aware about this and which channel is giving a reach to people in making education towards investing into mutual funds. The most important channels were banks and independent financial advisor were spreading the concept following which news paper advisement also played a prominent role. Lastly people also search about the concept on their own to explore and understand .lastly friends and colleagues also play role in spreading awareness to see and consider mutual fund as an avenue to invest in era. Even social media and mail marketing has its own weight age as an awareness tool. 
What are the reasons for not investing into mutual funds?

Reasons for not investing in Mutual Fund

\begin{tabular}{|l|l|}
\hline Not aware & $35 \%$ \\
\hline Aware but no reasons & $40 \%$ \\
\hline $\begin{array}{l}\text { aware but scared due to } \\
\text { market dynamics }\end{array}$ & $25 \%$ \\
\hline
\end{tabular}

Reasons for not investing in Mutual Fund
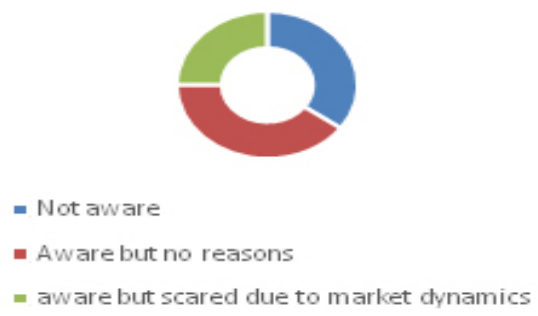

When population was asked the question about why they have not invested into mutual funds nearly 35\% said there are totally unaware about the concept in any way nor they have a idea of it, the second interesting fact is a segment of people are aware but for unknown reason they have not considered mutual fund as investment option at all among their portfolio, also one segment says that their aware but they are pessimist towards this as its linked with market in terms of investment and also returns based on market movements.

Are $\mathrm{u}$ aware that mutual fund is also investment option for investment?

Awareness about MF as an investment avenue

\begin{tabular}{|l|l|}
\hline Completely unaware & 40 \\
\hline partially aware & 21 \\
\hline aware but still doubtful & 18 \\
\hline completely aware & 21 \\
\hline
\end{tabular}

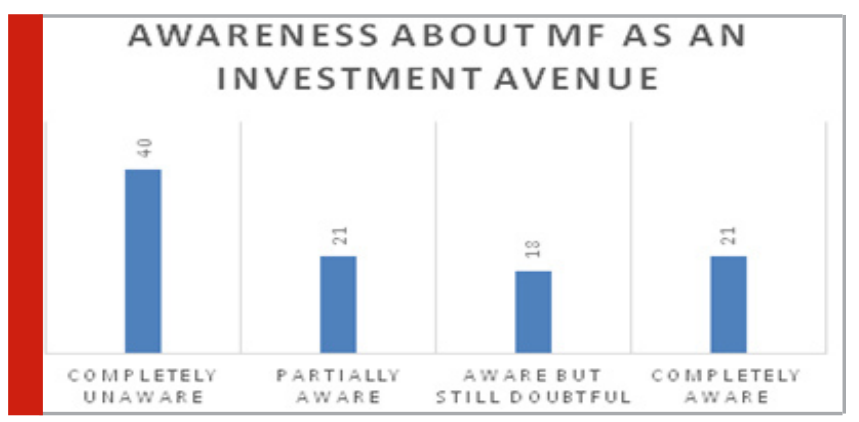

When the research tried to find out in which level can people be categorised in terms of awareness about mutual fund or if we want to where do people stand in awareness arena about mutual fund option nearly 40\% are completely ignorant of concept, secondly nearly $21 \%$ are partially aware about the concept as in earlier question its proved how various channels are playing a strong role in spreading awareness, there in one more very interesting segment which draws our attention that is people are aware but still doubtful on various elements involved in mutual fund in total. But nearly $21 \%$ of the population are completely understood the entire concept of mutual fund which is good sign of acceptance of this concept in a developing economy like India.

What the factors which have influenced you to invest into mutual fund as an investment?

Features of mutual funds that influences investment behaviour

\begin{tabular}{|l|c|}
\hline moderate return with less risk & 21 \\
\hline high return with high risk & 23 \\
\hline diversification of funds & 25 \\
\hline Tax savings & 11 \\
\hline Long term savings tool & 20 \\
\hline
\end{tabular}

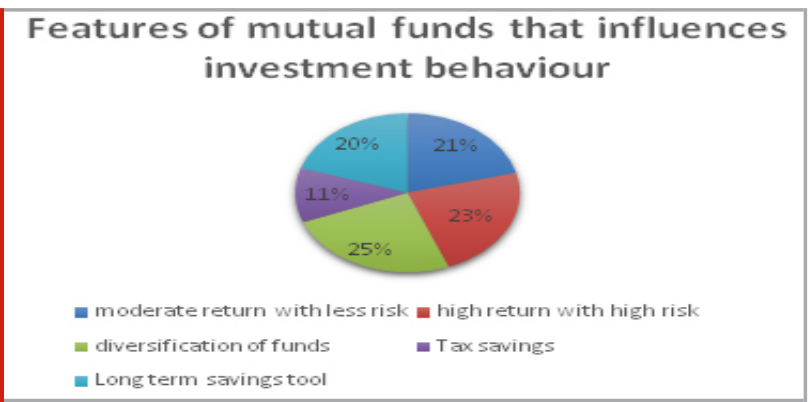

When asked the population what made them to invest into mutual fund the investigation revealed people feel when invested into balance fund it can generate moderate returns with less risk element, where as other segment felt investing into diversified equity and mid cap based fund and equity funds can generate higher returns with high risky if $\mathrm{u}$ have a risk appetite. whereas the how mutual fund works in terms of funds getting invested into various segments and also fund is not investing into a single equity component as all funds have a border horizon of investment as investment has a portfolios of debt ,bonds and equity holdings. The population also felt is can be invested for tax saving as few funds as generating tax savings under section $80 \mathrm{c}$ as equity linked savings schemes are eligible for tax saving and recognised by government. Few people are also revealed the mutual fund can become a long term investment for investment to achieve life milestones in pre designated time like children education, retirement planning etc.

What is your convenient mode to invest into mutual funds?

Preference for Mode of Investment

\begin{tabular}{|l|l|}
\hline One time investment & 47 \\
\hline Monthly systematic plan & 53 \\
\hline
\end{tabular}


Preference for Mode of Investment

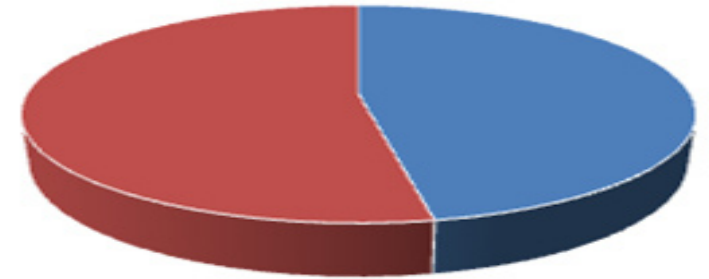

- One time imvestment

- Monthly systematicplan

The investor population when asked how do they prefer to invest into mutual's funds which mode is convenient to them to invest without hurting their financial planning majority $f$ them revealed systematic investment plan is preferred. As it gives the option to invest a specified amount on regular time like monthly on a specified date. Here a small amount can be invested regularly monthly to build a big corpus spread over a long period of time. The other population group revealed that they prefer to invest lump sum amount as and when they have a cash flow which can be invested into new fund offer or gong on funds based on fund growth.

There are various channels to invest into mutual funds, among these which channel do $\mathrm{u}$ feel comfortable to transact with and get services?

Preferred channel to buy Mutual Fund

\begin{tabular}{|l|l|}
\hline Through Independent financial advisors & 31 \\
\hline Through Banks & 38 \\
\hline Direct online Investments & 18 \\
\hline Direct manual investment & 13 \\
\hline
\end{tabular}

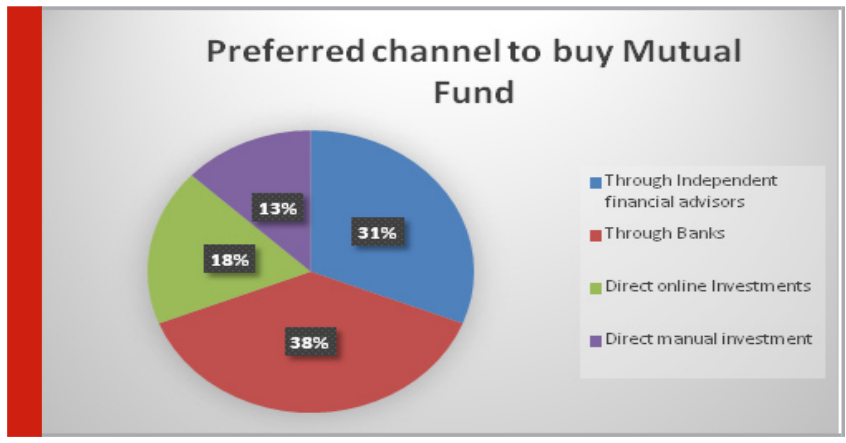

When the population was asked about the various channels which do sales and also service management of mutual fund investors, many of them preferred the banking channels as an easy way to transact and also get serviced because as banks are all ready into financial service and would had handle the clients portfolios earlier with history of relationship. Secondly people also prefer personal attention through independent financial advisor who give a personal touch to service required. The emerging channel such as online investment where the investors are searching about mutual funds on their own and also invest through the fund house website directly is also seen as a strong emerging channel. But there are very few people who go in search of mutual fund office in their respective places and invest voluntarily are very scarce.

Are you satisfied with the concept of mutual funds in terms of their fund performance and also the services given by the fund houses towards investors?

Overall satisfaction as a mutual fund investor

\begin{tabular}{|l|c|}
\hline Satisfied & 74 \\
\hline Not satisfied & 26 \\
\hline
\end{tabular}

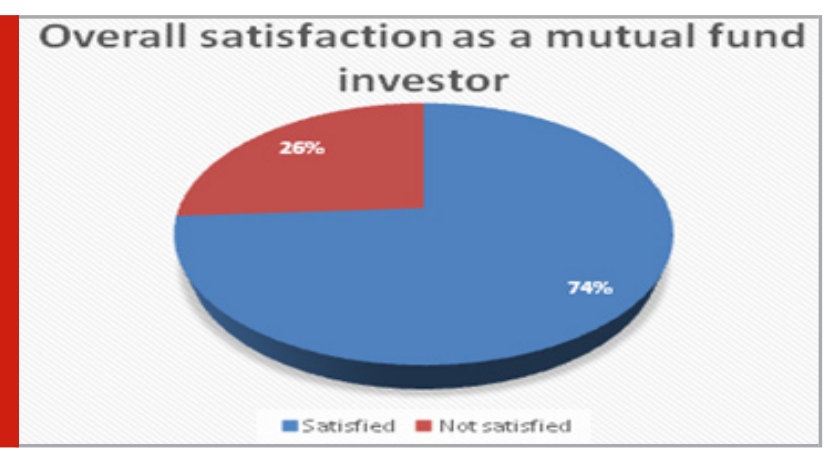

When the people who have invested into mutual funds and have stayed invested where asked about the question on how was the fund performance of the funds selected by them for investment or been advised to invested it generated a very positive response as nearly 74\% of the people told they are over all satisfied with the fund performance and also the various service given by the companies like investors knowledge enhancements, investors communications, fund switches, additional investment such as top ups and also the redemption services given are good and are meeting the expectations of the investors. A small group were not satisfied with mutual funds due to bad selection of mutual fund schemes and also they complained of changing regulation which makes investment into mutual fund a more tedious task.

\section{Findings of the Research}

- During the research it was found that evidently the mutual fund concept is not new to people but still in spite of so many fun houses and schemes launched still the awareness is very low which is an opportunity way ahead for growth of sector .

- People thinking is still aligned to traditional approach towards investment

- People can open to concepts and risk to return concept also has a weight age in gauging investment options.

- People with small income also have invested through systematic investment plan which is good way to accelerate the attitude of savings among economic population.

- People have not invested into mutual funds due to unknown reasons which is consumers black box which has to tapped to make the concept a 
knowledge version for its penetration among the ignorance segment.

- $\quad$ Online mode of investment where the client studies and chooses plans suitable for his needs are emerging on a positive note.

\section{Suggestions}

- Mutual fund companies have to open small branches of their own in tier 2 cities and town level, where the reach can be done through investor education programmes. In the village level the gram panchayat meetings can be made knowledge sharing and discussion forum to spread the concept as during the study it was mainly concluded that lack of awareness and also aware but not completely was found this requires a knowledge approach to spread the concept and tap the rural masses who can be benefited by this investment options.

- As banks are seen as a strong financial service provider by the population more emphasis with bank ties and distribution of mutual funds through banks can do a drastic change in tier 2 cities and village level, as people's confidence with banks can be capitalized to approach and educate.

- Even post offices can be seen a future service and sales point in the most remote areas to reach the population as postal departments already have savings schemes and postal insurance can be utilized and product bundling can be made to spread the concept.

- Online investors awareness has to conducted as to tap the educated and young earning population who can be educated at a young age and be given opportunity to invest for long time and reap the benefits of mutual fund schemes in order to achieve the financial milestones in a planned phases.

- People have also revealed a strong likely towards government owned mutual fund schemes during the study which indicate that government's banks and financial institutions have ample opportunities to venture into mutual fund business and build on peoples trust in turn contribute to the circular flow of economic cycle.

\section{CONCLUSION}

The study as revealed that mutual fund concept is still in a nascent stage of its growth cycle as people are unaware of these and mainly in tier - 2 cities there is ignorance at large, also people are half educated about the concept. It's the failure of mutual fund companies on these fronts of not exploring these areas .Few people have shown a keen interest in concept which clearly concludes that still people have to educated, marketing or sales concept cannot be applied to this financial instruments as it's a knowledge game .people to have understand then invest because it's a long term engagement between the clients and fund houses. Banks can be a major game changer if they venture into mutual fund business and penetrated properly to the rural markets where the next investment play ground can be set to make a fair play of investment acquisition and giving back a fair returns to the population can create a balanced economy to drive India towards developed nation's league.

\section{REFERENCES}

A.V.V.S.Subbalakshmi and R.Balachandar,,(2017) A Study on Investor's Attitude towards Mutual Funds as an Investment Option, Proceedings of the Tenth AsiaPacific Conference on Global Business, Economics, Finance and Social Sciences (AP17Hong Kong Conference) ISBN: 978-1-943579-97-6 Hong KongSAR. 20-22, January 2017. Paper ID: HK703

Dr. J K Raju , Mr. Manjunath B R , Mr. Sachin ,(2018) A STUDY ON INVESTORS ATTITUDE TOWARDS MUTUAL FUND AS AN INVESTMENT AVENUE, JETIR (ISSN2349-5162)

https://economictimes.indiatimes.com/

https://www.ft.com/

https://www.sebi.gov.in/

Mr. Erram Ramesh(2018) A Study of Investors Attitude towards Mutual Fund, International Journal of Engineering Technology Science and Research IJETSR www.ijetsr.com ISSN 2394 - 3386

www.amfi.com 